\title{
The Role of Scandal in the Political Life of Italy during the Period 1976-2011
}

\author{
Elena Proskurina
}

\author{
PhD student, Lomonosov Moscow State University, Assistant professor, Plekhanov Russian University of Economics
}

Email: euproskurina@gmail.com

\author{
Doi:10.5901/mjss.2015.v6n1s1p333
}

\begin{abstract}
This research was conducted to examine the relations between political culture in Italy and its political scandals in the XX century and their impact on the failure of so-called "The First Italian Republic" regime in the 1990-s. The research covers the most significant political scandals from the "Propaganda Due" to the most famous "Tangentopoli". The findings revealed that political scandal is a turning point in the modern democracy, which reveals the main system problems and gives a chance to the government to estimate the political risks and take an action to prevent the following worsening of the situation. Also the results of the research present an attempt to systemize on the base of the most recent data published in academic sources and classify and leading media political scandals according their actors, reasons and consequences as well as coverage in the media.
\end{abstract}

Keywords: political scandals; modern politics; Christian democrats; Italy

\section{Introduction}

Nowadays, in modern societies the interest in politics is fairly high, thus Media covers both public and private lives of politicians to satisfy this interest. The hot topic of modern mass media has become diverse political scandals occurring in different parts of the world. This research is devoted to the role of a political scandal in the political life of Italy during the period 1976-2011 and might be useful for those, who are interested in political history of Italy in the $20^{\text {th }}$ century or in developing trends in modern politics in democratic countries.

The aim of this research is to demonstrate that a political scandal has a dual nature in the modern politics: on the one hand it is a negative factor, which denudes all the drawbacks of politicians, while on the other hand it simplifies problem-solving and provides new opportunities for the radical changes.

The scandal is one of the ways to attract attention, or vice versa to destroy someone's image. The manipulation of public opinion includes scandolology as one of the methods. This term implies a study of the phenomenon of scandals, describes the scientific discipline which examines the phenomenon of scandals. The term of "scandolology" was coined in 1985 by researcher Anthony King (1985). In 1985, a British political scientist Anthony King conducted a comparative analysis of the British-American scandals. He ironically called his research scandolology, after what the development of scandolology started (1985, as cited in Markovits A.S., Silverstein M., 1988, p. 2)

\section{Research Method}

The material for the research are the newspaper articles of Italian, British, American, Russian and Soviet publications, covering the period which is studied and events relating to the object and the subject of this research. To lay down a base of research material we also used legislative documents of the Italian Republic and statistics.

Scandolology is the serious study of the political scandals, due to the actions of today politicians this science develops rapidly, become a sub discipline of political science, sociology and anthropology. As science scandolology studies scandal through the prism of time and culture of the country in which it arises and develops, so much attention is paid not to describe features of scandal, but on its influence on the subsequent development of the state.

\section{Analysis Result}

Most serious studies explore the specific scandals, as the most part of scandals and their consequences (the official investigation and the press) helps to obtain the reliable information about the situation in the state. Scandolology examines the reality in the state and allows to compare and to judge the political systems. 
Scandal is a special technology aimed to realize the political objectives. Thus, as a special case of the political technology a political scandal is characterized by the following features:

1. Instrumental, because it is used as a tool to create the image.

2. Depending on the extent and area of impact a political scandal can be both state-national, if the events, provoked by a scandal, are important in the frameworks of the state, and regional-continental, if we talk about the image of the figure, who is significant for the region not limited by national borders, for example, plays a significant role, in supranational entities and international organizations. The political scandal can be corporate, for example, if the consequences affect intra-party relations, and local.

3. Depending on the rate of achieving the result and periodicity a political scandal is tactical, strategic and cyclic.

4. As most political scandals have a similar scenario of execution and development, it means a political scandal is replicated.

5. Softness in selecting resources and means to achieve goals.

6. Deviance.

7. Shady character, despite the fact that a political scandal is replicated as the share of the spontaneity in organization of the scandal and the hidden preparations for its implementation are still present.

In politics, the scandals arise from a certain number of things: corruption, untruthfulness, sexual relations.

Andrew Markowitz (Professor at the University of Michigan) and Marc Silverstein (Professor at Boston University) are the creators of one of the most complete works, dedicated to political scandals in Europe (UK, France, Italy, Germany, Austria), America (USA, Canada), Asia (Japan) making their work fundamental as the most studies have been dedicated to the certain political scandals. In their work "Politics Scandal: Power and Process in a liberal democracy" (1988) these authors see an opportunity in scandals for studying the condition of the state on micro- and macro-level, as due to the scandals society knows the facts which has previously been hidden carefully and the problems of the state, so that governments and the political elite are replaced, the new honest partnerships are established (Markovits A.S., Silverstein M., 1988)

They are distinguished into two basic types of any political scandal: "procedural" and "real". Under the first they understand the scandal arising from the incorrect actions of the state structures, or any kind of the actions of the investigative bodies, under the second they meant publish results of the personal life of the powerful people, which contradicts the norms of behavior (there are the sexual adventures among them). According to them, the first kind of the scandals are much more important for the state, but the "real" scandals attracted much more attention and tend to lead to the serious consequences. Markowitz and Silverstein also note that the political scandals occur only in liberal societies (Markovits A.S., Silverstein M., 1988) - in totalitarian and authoritarian regimes, the media has few opportunities to get and to disseminate information about the illegal actions of the officials.

Studying the phenomenon of the scandal in politics it is necessary to allocate a very important feature of this phenomenon, namely the role of the media in the development of the political scandal, therefore the impact on public opinion. The mass media has become a tool, regularly used by the political actors.

John Thompson (Professor of Sociology, University of Cambridge) says that the scandals attracting people's attention through the work of the media make go beyond the bounds the rules of a more trivial in people's minds, i.e. establish a rule that has been condemned (Thompson J.B., 1995) The scandalous information causes resentment of "the policy on occasion" among the common man and at the same time it creates a sense of active participation in the political process. People sympathizing participants of the scandal get an emotional discharge. Thus, the scandal as an extraordinary social and political phenomenon acts as a strategy of the change of the public consciousness and emotional release if there are tensions.

Besides the influence of the mass media on ordinary people, the media are also important for researchers of the political scandal as it is the main source material for the study of the scandals, which highlights almost all stages of development of a political scandal, which have been appropriated by Professor of sociology McNeese State University of Louisiana Stan Weeber. According to this study, the political scandal takes the following six stages of development (Weeber S., An international perspective on political scandals, 2008, p.3):

1. Accusation. The media receives information about policy actions that are contrary to good morals or laws; there is the publication of this information.

2. The answer of the "victim". The accused-"victim" of the scandal states his position on the accusation, often he denies his involvement.

3. Conflict. The mass media highlights the further development of the scandal: the investigation, the response of government, family members and friends of the accused, the public opinion.

4. Rapid development. The scandal reaches its peak, the investigation seeks the most important political figures 
at this stage, and the importance of the first "victim" of the scandal is not so significant.

5. Punishment. There is a subsidence of the scandal, the mass media highlights the trials, and then the punishment of members of the political scandal follows.

6. "Decoupling" is the end of the scandal, the consequences ensue. The last stage of the scandal cannot be achieved immediately after experiencing, but after some time.

The following conclusions are made based on this study: scandal is a technology, which is used to influence public opinion concerning the image of the politician or political party, who is a participant of the political scandal.

It is very problematic to diverse the scandals due to their variety. In this paper the theory was accepted that the scandal was part of the political technology, therefore it was characterized by its characteristics: instrumental, the scale effects (continental-regional, state-national, corporate, local), the rate of achieving the results (tactical, strategic, cyclic), replicability, softness selection of resources and facilities, deviance, the shadow type of organization.

The typology of the political scandals isn't fixed clearly, too. Several viewpoints are presented in this paper, one of which is a journalistic, but it is not clear sufficiently, so it is unified to 5 types: a vice, an economic crime, abuse of power, defamatory environment and espionage. Another viewpoint belongs to the political scientists $\mathrm{A}$. Markowitz and $\mathrm{M}$. Silverstein. They divide procedural scandals (arising from the incorrect actions of the state structures), and real (about the politicians 'private life). The analysis of Italian scandals has showed that Italy is characterized by a mixed type of scandals (the real scandals develop to procedural). Nowadays the role of the media is great as the politicians regularly use it as a tool; especially it concerns the social media. An ordinary man has an impression of active participation in political life in regular highlighting of the scandals in the media, but the permanent lighting of censured public morality facts reduces the perception of these facts as an undesirable behavior. In addition, the media has impact on people; they still are the main source of the material for the study of scandals at all levels of their development. The stages of development of the scandal were defined by S. Weeber. They are 6: the accusation, the answer is "victim", the conflict, the rapid development of the punishment, "decoupling".

Among all political scandals occurred in Italy were chosen the most significant: Aldo Moro's kidnapping and murder, "Propaganda 2", "Tangentopoli".

Aldo Moro's kidnapping and murder is not the first scandal in Italy, but it has a serious impact on the balance of political forces in the state. "Red brigade" admitted that they attacked the most influential party of postwar Italy - the Cristian Democrats in the face of Aldo Moro. Aldo Moro is not only the face and symbol CD but he also initiated cooperation between the Christian Democrats and the Left Opposition, which also influenced on the terrorists' choice of victims. As the crime was committed during the Cold War in Italy, and which fell into the area of interest both the United States (geographical location), and the USSR (the popularity of left-wing ideas in Italian society), this scandal had significance of the continental-regional level. The consequences were rapid dismantling of "historic compromise" policy, the end of cooperation between the Communists and the CD; decrease the authority of the Communist Party. The impact of the scandal on the future life lied in the fact that the suspicion of involvement in the crime caused great resonance and destroyed the image easily.

- Illegal Masonic lodge "Propaganda 2" provided such a serious impact on the administration of the state that the press called it a "state within a state" and «shadow government».

The feature of this scandal has been the rapid development from local scandal (the investigation of Michele Sindona's and Roberto Calvi's personal activities) to corporate (a matter of the bank "Ambrosiano"), and then to the state level (the relations between financiers, the representatives of mafia and the members of the government). The investigation of the scandal proved the involvement of lodges to the political killings (Aldo Moro, General Dalla Chiesa Charles Albert, journalist Mino Pecorelli), relations with the mafia and financial fraud, demonstrated the weakness of the political system, which makes possible the criminal impact on governance of the state. Politicians' participation discredited CDA and COI parties, made Arnaldo Forlani's government resignin 1981, provoked a political crisis that erupted during the scandal of "Tangentopoli".

- "Tangentopoli" is a consequence of the unsolved questions as curtained during the investigation of the Masonic lodge "Propaganda 2" and the desire of Italy to modify according to the requirements of the Maastricht Treaty. There was rapid development from the local to the state level in the scandal "Propaganda 2". The accusations were all the same: corruption, bribes, relations with the mafia, political assassinations. The difference was the involvement of all old parties, and then the new parties. The scandal of "Tangentopoli" became the catalyst for the collapse of the First Republic and the formation of the Second. The main outcome of these investigations was the political instability, which was expressed in the frequent changes of governments due to the inability to function outside the coalition and the growth of the nationalist sentiments among the population, which explained the success of such parties as the "National Alliance" and "Northern 
League" and allowed the party Silvio Berlusconi to occupy leading positions in a political vacuum.

Based on the analysis of the scandals presented in the paper, it can be determined the main reason why corruption and relations with the mafia were typical of the Italian ruling elite. The reason was the imperfection of the political system, the existence of so-called "blocked democracy", the inability to cooperate with the opposition Christian Democratic Party. Long concentration of power in the hands of one party and a majority in Parliament were allowed to take the CDA any laws which gave rise to corruption and allowed the mafia to increase its influence.

In consequence of such relations it is most typical for Italy the following types of scandals: economic crimes and abuse of power. Most of the scandals begin with an investigation on suspicion of corruption, then relations between politicians and businessmen with the Mafia reveal, the assassinations are disclosed. For Italy, it is significant the fact that all subsequent scandals concern to the previous ones and even the participants (the parties and politicians) remain the same. It allows to suggest in spite of the fact that the scandals provoke reaction in society, promote the detection of crimes and the political reforms, the reasons of the scandal are not eliminated but are merely hidden during several years.

Silvio Berlusconi entered big politics at the height of the greatest political scandal of "Tangentopoli". In politics he was a new actor, but even when he was a businessman, his name was implicated in several scandals including the "Propaganda 2". Despite the fact that Berlusconi's party won the elections, the scandal of "Tangentopoli" touched on him and Berlusconi received a vote of censure and was forced to resign. The scandals and lawsuits began to pursue Berlusconi since the early 80s, when he became a media magnate. Berlusconi's success and his media empire are explained by his friendship with Bettino Craxi and patronage of the latter, making laws that created the conditions for Berlusconi to have all the chances to become a monopoly. The first loss of Berlusconi-business owner, the cause of which was the scandal of "Tangentopoli", was the resignation, the tribunal and exile of Craxi, i.e. the business remained without support from the government. Most likely, it was the reason why Berlusconi was interested in politics himself, organized a party and managed to win the election.

Since 1994, Berlusconi has been both a successful businessman and politician, this combination causes the reason for the frequent scandals around him. The reason lies in the fact that Berlusconi has a conflict of politicianbusinessman's interest: he was accused of financial frauds, nonpayment of evasion, bribe of the judges and relations with the Mafia, and he used the issue of new laws or amendment for either receiving immunity of the position, or reducing statute of limitations of the cases, thereby avoiding responsibility. In addition, using his controlled media Berlusconi can deliberately create yourself so scandalous image, in which his vices and crimes will be viewed as features which are valued in the Italian society, such as funding from the Socialist Party headed Craxi in exchange for the favorable laws he adduces as strong friendship.

Thus, on the basis of this work it can be concluded that the political scandals are the result of the political crisis, but they allow us to understand the most acute problems and make decisions on their elimination. In Italy the elimination of these problems is only visibility, as the political scandals are a chain of connected events which are provoked by not completely eliminated causes of the previous scandals.

The role of the scandals is not ambiguous, on the one hand, they are simplified problem-solving, provide an opportunity to implement the radical changes, allow new actors to enter the political arena. On the other hand, they cause instability, destroy the existing party.

\section{References}

Berlusconi si dimette, la Lega a pezzi// II Corriere dele Sera, Milano, 23 Dicembre 1984

Borsa M., Calvi ha scelto di fuggire all'esteronon poteva piu'guidare l'Ambrosiano// La Stampa, Torino, 17 Giugno 1982, №125

Cantoni R., Si uccide la segretaria del banchiere// La Stampa, Torino, 18 Giugno 1982, № 126

Caso Sme verso la sentenza// II Corriere della sera, Milano, 26 Ottobre 2004

C. de Gregorio, "Giustizia, tv, ordine pubblico è finita proprio come dicevo io"// La Repubblica, Roma, 28 Settembre 2000

Colli L., Cade al primo ostacolo il decreto TVI/ La Repubblica, Roma, 29 Novembre 1984

Cowell A., Kickback scandal convulses Italy/l The New York Times, New York, 10 May 1992

Cowell A., Scandal produces a hero//The New York Times, New York, 5 March 1993; Polla Paola, L' ex pm ha superato la soglia dell' eroe E' inattaccabile: 8 su 10 lo sostengono//Corriere della Sera, Milano, 11 Dicember 1996

D. McLaughlin. Scandalology: a beginner's guide to the political scandal.//The Weekly Standard. 31 January 2006

Ecco I nomi della Loggia P-2// La Stampa, Torino, 21 Maggio 1981, №119

Fabrizio De Santis. La lettera di Paolo VI alle Brigate rosse// Corriere della sera. 23 Aprile 1978

Fazzo L., Craxi e Berlusconi condannati insieme /La Repubblica, Roma, 14 Luglio 1998

Giuliano Amato presidente del Consiglio// II Corriere della sera, Milano, 25 Maggio 1992 
II Lodo Alfano è incostituzionale// La Stampa, Roma, 7 Ottobre 2009

II messaggio delle $\mathrm{Br}$ // Corriere della sera. 19 Marzo 1978

La famiglia alla procura: riaprite il caso Moro// La Stampa, Torino 11 Novembre 2003

Le Br alzano il tiro: rapito il giudice Sossi //Corriere della sera. 18 Aprile 1974

Le dimissioni del governo Forlani// La Stampa, Torino, 26 Maggio 1981, № 144

Masons linked to mafial/ the Guardian, London, 08 March 1986

Massonic boom shakes Italy/l the Guardian, London, 27 May 1981

Milano, l'onta delle tangenti// II Corriere della Sera, Milano, 30 Aprile 1992

Moro all'USSR serviva vivo// La Repubblica, Roma, 26 Marzo 1992

Obituary: Franco Di Bella //The Independent, 23 December 1997

Oggi Scalfaro dara' l'incarico al professore//La Stampa, Torino, 16 Maggio 1996

Petta G., L'agente superstite: vivo per miracolo// II Corriere della Sera, 21 Agosto 1992

Poletti F., Tangenti all'ospizio, arrestato il presidente// La Stampa, Torino, 18 Febbraio.1992

Processo Mills, Silvio Berlusconi prosciolto per prescrizione// II Corriere della sera, Milano, 25 febbraio 2012

Referendum, si vota per cambiare//la Stampa, Torino, 18 Aprile 1993, №106

Scandal in Italy is bringing calls for the socialist leader to resign// The New York Times, New York, 17 December 1992

Scottoni F., Tre pretori contro I Colossi TVI/ La Repubblica, Roma, 17 Ottobre 1984

Silvio non rinnega mai gli amici// II Corriere dele Sera, Milano, 24 Novembre 1995

Soldi alla DC, 7 mesi a Paolo Berlusconi//, 23 Dicembre 1994

Soldi alla DC, 7 mesi a Paolo Berlusconi//Il Corriere della sera, Milano 23 Dicembre 1994, P.11

Suro R., Switzerland extradites fugitive Italian financier// the New York Times, New York, 18 February 1988

Tangenti alle Fiamme gialle assolto Silvio Berlusconi// La Repubblica, Roma, 19 Ottobre 2001

Tangentopoli, cdm approva decreto Conso// II Corriere della Sera, Milano, 5 Marzo 1993

Tornabuoni Lieta, L'ingenere delle tangenti// La Stampa, Torino, 20 Agosto 1992

US envoy admits role in Aldo Moro killing// The Daily Telegraph, London, 11 Marzo 2008

Archivo storico delle elezioni- Consultazioni dati// Dipartimento per gli affair interni e territoriali http://elezionistorico.interno.it/index. php?tpel=C\&dtel=05/04/1992\&tpa=I\&tpe=A\&lev0=0\&levsut0=0\&es0=S\&ms=S

Decreto legge 20 ottobre 1984, n. 694 http://www.normattiva.it/uri-res/N2Ls?urn:nir:stato:decreto-legge:1984;694

"Italia dei Valori" [электронный ресурс] - Режим доступа: http://www.italiadeivalori.itlindex.php

La costitzione italiana, Parte I, Titolo 1, Articolo $18 \mathrm{http}: / / w w w . c a m e r a . i t / 55$ ?indice_costituzione=2\&costituzione_numeroarticolo= Art.\%2018

Legge 6 agosto 1990, n. 223, http://www.normattiva.it/uri-res/N2Ls?urn:nir:stato:legge:1990;223

Legge 20 giugno 2003, n. 140 www.camera.it/parlam/leggi/03140l.htm

Legge 23 luglio 2008, n. 124 http://www.camera.it/parlam/leggi/08124L.htm

Gilbert M., Italy's third fall// Journal of modern Italian studies , 2:2,1997, P. 221-231

Jones E., Wheeler dealers: Silvio Berlusconi in comparative perspective//Journal of modern Italian studies, 14:1, 2009, P. 38-45

Kolovos I., Harris P., Political Marketing and Political Communication: the relationship revisited, 2005

Markovits A.S., Silverstein M., The politics of scandal. Power and process in liberal Democracies, New York, 1988

Sassoon D., Tangentopoli or the democratization of corruption: considerations on the end of Italy's first republic// Journal of Modern Italian studies, 1:1, 1995, P. 124-143

Thompson J.B., The media and the modernity: a social theory of the media, Cambridge, 1995

Tocci N. Power or policy: a comparative study of the cohesion of Italian coalition governments in the First and Second Republics/l Journal of Modern Italian Studies, 5:1,2000 P.61-79

Weeber S., An international perspective on political scandals//MPRA paper, Munich, 30 June 2008 